\title{
Physical design development for evaluate digital library application based on modified CSE-UCLA with weighted product
}

\author{
Dewa Gede Hendra Divayana, ${ }^{1, *}$, P. Wayan Arta Suyasa $^{1}$, and Ida Bagus Gede Surya Abadi \\ ${ }^{1}$ Universitas Pendidikan Ganesha, Department of Information Technology Education, Jl. Udayana No. 11 Singaraja, Bali, Indonesia \\ ${ }^{2}$ Universitas Pendidikan Ganesha, Department of Primary School Teacher Education, Jl. Udayana No. 11 Singaraja, Bali, Indonesia
}

\begin{abstract}
Digital library as one of the supporting services of information technology-based learning process has been found in many universities, but in the implementation, there are still many obstacles. Therefore, it is necessary to evaluate using appropriate tools to obtain accurate results. Based on that, the primary purpose of this paper is to explain the physical design of applications that apply the modified CSEUCLA model with weighted product method, so it can be used to evaluate the digital library. Subjects involved in conducting trials on this application for digital library evaluation are four peoples consisting of two educational experts and two informatics experts. The location of the experiment was done in one of the computer universities in Bali Province. The tool used to collect data of trial result is in the form of questionnaires. The analysis technique used is descriptive quantitative concerning the quality percentage of each trial aspects. The results obtained from this study were average percentage of evaluation application quality of $92.00 \%$ belonging to the excellent category, so it can be concluded in general that applications were ready for use to evaluate the quality of digital library services.
\end{abstract}

\section{Introduction}

There are various information technology-based services used in helping the learning process in universities, including blended learning, e-learning, digital library, emodule, and others. The emergence of various information technology-based services in universities occurred due to rapid advances in the field of information and communication technology. The advancement of information and communication technology has a tremendous influence in various fields, including in the field of education which enables the learning process to be well facilitated through the help of information technology, especially computer [1]. One of the most important services of various information technology-based services those were utilized in the field of education and become a requirement of a universities accreditation, so the existence of digital library needs to be optimized. Besides, the digital library as one of the important services, because it becomes information technology-based services that must be available in universities to facilitate academic community in searching the source/teaching materials supporting the courses learned and other digital collections to support the learning process.

But the reality that occurred in the field, not all universities can organize digital libraries optimally. There is even a college in the field of computer, which provides digital library services only as a formality for completeness of accreditation without running the process business of digital libraries well. Based on the problem of evaluation activities is certainly needed in obtaining a recommendation improvement of digital library services to be more optimal. The meaning of the actual evaluation activity to obtain results that can later be used as a recommendation in taking a decision. The meaning is essentially the same as the research studies on the evaluation that has been done previously by Divayana [2-6], Suandi, Putrayasa and Divayana [7], Arnyana, et al.[8], Jampel, et al.[9], Divayana, Ardana, and Ariawan [10], Divayana and Sanjaya [11], Divayana, et al. [12-15], Divayana, Adiarta and Abadi [16-19], Divayana and Sugiharni [20], Ariawan, Sanjaya and Divayana [21], Wahanani, Suartana, and Hasyim [22], Lee, et al. [23], Xuesheng and Liyingi [24], Li, et al. [25], Suhaimi, et al. [26], Fatahillah, et al.[27], Burhani, Zukhruf and Frazila [28], Calmanoa, et al. [29], and $\mathrm{Xu}$, et al.[30].

In order to obtain an evaluation result that can show a good quality average value in terms of components that can indicate the initial state of the system, the components can indicate an alternative choice to meet the needs of the program, a component that is able to introduce information about the program, components that are able to show information about the function/performance of the program, and the capable components that show information about the benefits of the program. Besides, the evaluation results are also able to show the percentage of quality ranging from the smallest percentage to the highest in each evaluation component. Given the need for such evaluation results, it is necessary to develop appropriate evaluation

\footnotetext{
* Corresponding author: hendra.divayana $@$ undiksha.ac.id
} 
applications as their solutions. The evaluation application that can be developed in the form of evaluation application based on the modification of education evaluation model that is CSE-UCLA by using decision support system method that is a weighted product. Based on the existing problems and general idea for problems solving, then the problems formulation in this paper are: 1) how is the physical design of application for digital library evaluation based on modified of CSE-UCLA evaluation model by using weighted product method?, 2) how is the result of user response to the physical design of the application?

This research arises because based on the obstacles found in research that has been done before in 2016 by Divayana [31] that the evaluation of expert digital library based on the expert system in one of the universities in Bali province still not able to show the evaluation result from the lowest value until the highest of each component of the evaluation, so it has not yet been found with certainty that the priority aspects must be improved on each component of the evaluation.

\section{Method}

This study is a development research, using 10 stages of Borg and Gall development model [32], which consists of 1) research and information collecting, 2) planning, 3) develop preliminary form of product, 4) preliminary field test, 5) main product revision, 6) main field test, 7) operational product revision, 8) operational field testing, 9) final product revision, and 10) dissemination and implementation. In particular, the study of this paper only discusses the stages of developing preliminary form of product and preliminary field test, because it refers to the formulation of predetermined problems related to the physical design of the application and the user's response to the physical design. To find out the results of the user's response to the physical design, then conducted a trial involving four users, they are two informatics experts and two education evaluator. The location of this trial was in one of the computer universities in Bali Province. The tool used to collect the results of user responses in the form of questionnaires. The analysis technique used in this study was quantitative descriptive. The physical design of an application for digital library evaluation based on modified CSE-UCLA with the weighted product can be shown in Figure 1 to 3.

The formula used in the normalization process is the vector-S formula in the weighted product method, which is shown as follows [33-35].

$$
S_{i}=\prod_{j=1}^{n} x_{i j}{ }^{w_{j}}
$$

With $\mathrm{i}=1,2, \ldots \ldots . ., \mathrm{m}$, and å $\mathrm{j}$ must be worth $=1$ where:

$\mathrm{S}$ : alternative preference values of normalization result

$\mathrm{x}$ : criteria value

w : criteria weight

$\mathrm{n}$ : number of criteria
$\mathrm{W}_{\mathrm{j}}$ is a rank that is either positive or negative. The positive value for profit attribute, and the negative value for cost attribute.

The determination of evaluation result based on the ranking process using the vector- $\mathrm{V}$ formula in weighted product method, which is shown as follows [33-35].

$$
V_{i}=\frac{\prod_{j=1}^{n} X_{i j}{ }^{w j}}{\prod_{j=1}^{n}\left(X_{j}\right)^{w j}}
$$

where:

$\mathrm{V}$ : The relative preference value of each alternative for ranking

X : Criteria value

w : Criteria weight

The alternative chosen is the alternative that has the highest preference value.

The average category of trial results of the application for digital library evaluation follow the converting of quality percentage to scale 5 [36], showing the details as follows: 1) excellent category with 90$100 \%$ percentage range, the good category with $80-89 \%$ percentage range, enough category with $65-79 \%$ percentage range, less category with $55-64 \%$ percentage range, and poor category with $0-54 \%$ percentage range.

\section{Results and discussion}

The main menu of an application for digital library evaluation based on modified CSE-UCLA with the weighted product is shown in the following figure 1 .

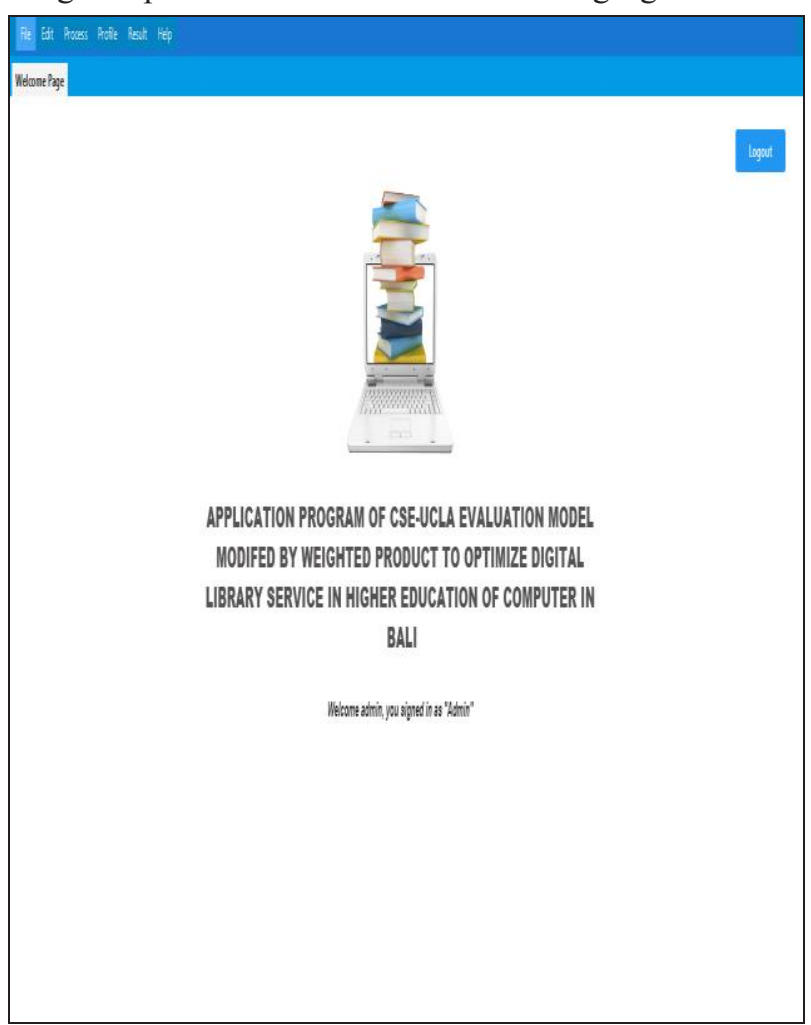

Fig. 1. Display of Main Menu.

The normalization form of an application for digital library evaluation based on modified CSE-UCLA with the weighted product is shown in the following figure 2 . 


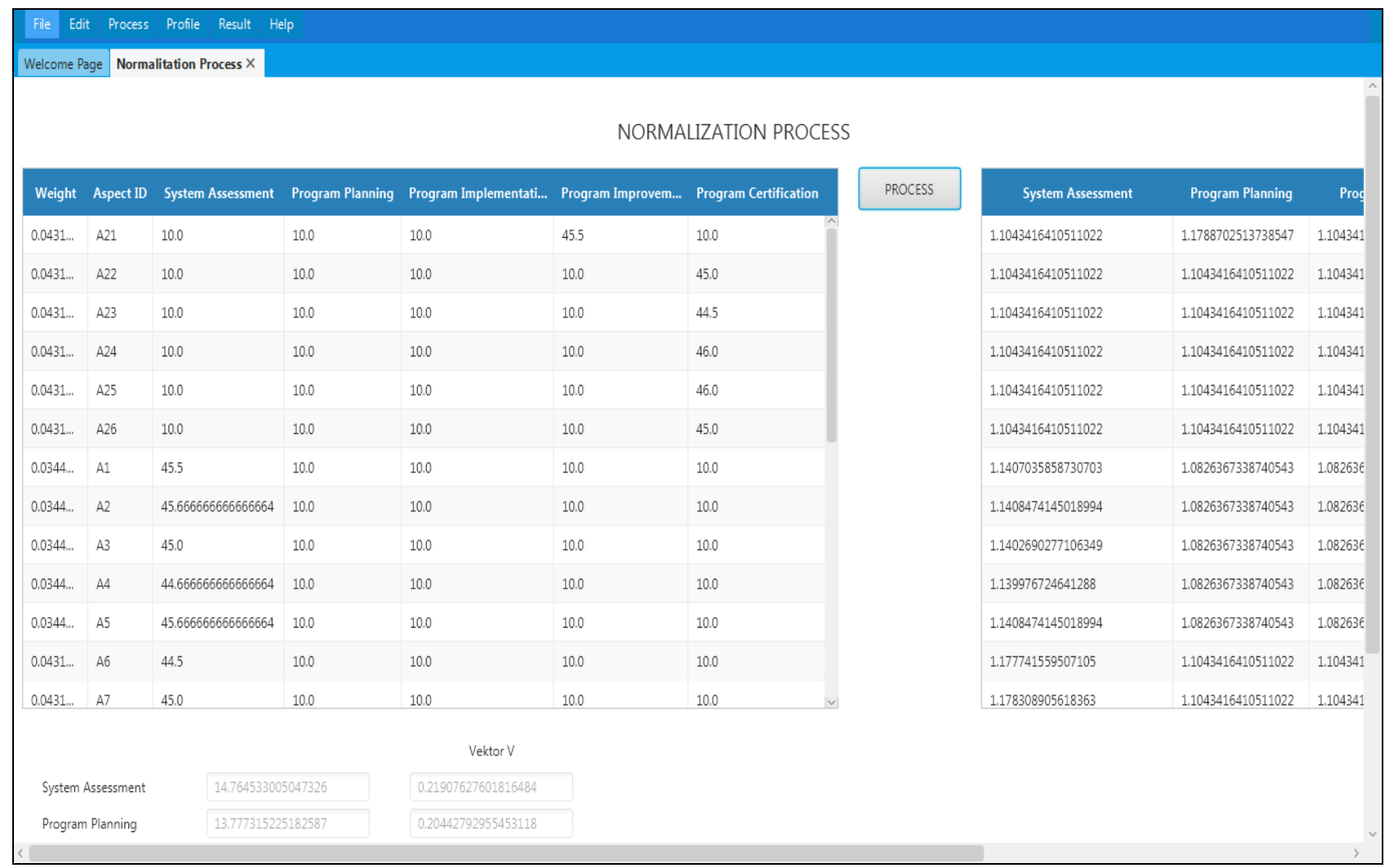

Fig. 2. Display of normalization form.

The evaluation result form of an application for digital library evaluation based on modified CSE-UCLA with the weighted product is shown in the following figure 3 .

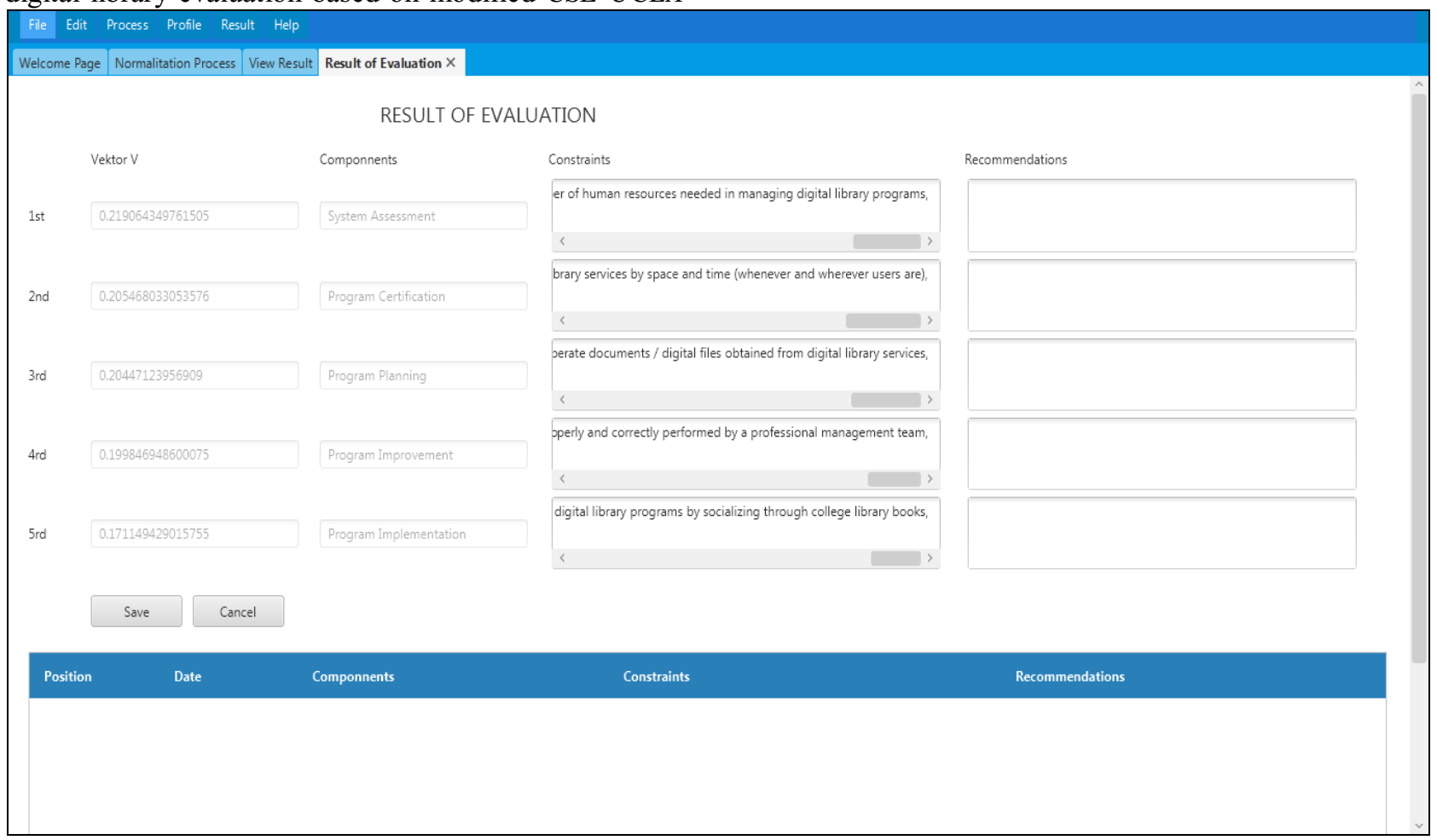

Fig. 3. Display of evaluation result form.

Figure 1 shows display of the main menu that serves as the main gateway in connecting to other forms. Figure 2 shows the display of normalization form used to perform the multiplication of attribute ratings after first being powered by the attribute weights. Figure 3 shows the display of evaluation result form. The trial results of an application for digital library evaluation by four respondents involved can be seen in following Table 1 .

*Corresponding author: hendra.divayana@undiksha.ac.id 
Table 1. Trial results of application for digital library evaluation by respondents.

\begin{tabular}{|c|l|c|c|c|c|c|c|}
\hline \multirow{2}{*}{ No. } & \multicolumn{1}{|c|}{ Trial Aspect } & \multicolumn{3}{c|}{ Respondents } & \multirow{2}{*}{$\begin{array}{c}\text { Percentage of } \\
\text { Quality }\end{array}$} \\
\cline { 3 - 5 } & & R1 & R2 & R3 & R4 & & \\
\hline 1. & Conformity and accuracy of login design & 5 & 4 & 4 & 4 & 17 & 85.00 \\
\hline 2. & Conformity and accuracy of main menu design & 4 & 4 & 5 & 5 & 18 & 90.00 \\
\hline 3. & Conformity and accuracy of user data input form & 4 & 5 & 4 & 5 & 18 & 90.00 \\
\hline 4. & $\begin{array}{l}\text { Conformity and accuracy of the form design of interest rating } \\
\text { score input by admin }\end{array}$ & 5 & 5 & 4 & 5 & 19 & 95.00 \\
\hline 5. & $\begin{array}{l}\text { Conformity and accuracy of the form design of decision- } \\
\text { making preference weights }\end{array}$ & 5 & 5 & 5 & 4 & 19 & 95.00 \\
\hline 6. & $\begin{array}{l}\text { Conformity and accuracy of the form design of interest rating } \\
\text { score input on each evaluation aspect by user }\end{array}$ & 4 & 5 & 5 & 4 & 18 & 90.00 \\
\hline 7. & $\begin{array}{l}\text { Conformity and accuracy of the form design of calculation } \\
\text { average value of each aspect }\end{array}$ & 5 & 4 & 4 & 5 & 18 & 90.00 \\
\hline 8. & $\begin{array}{l}\text { Conformity and accuracy of the form design of } \\
\text { normalization process }\end{array}$ & 5 & 5 & 4 & 5 & 19 & 95.00 \\
\hline 9. & $\begin{array}{l}\text { Conformity and accuracy of the form design of ranking } \\
\text { process }\end{array}$ & 5 & 5 & 5 & 4 & 19 & 95.00 \\
\hline 10. & $\begin{array}{l}\text { Conformity and accuracy of the form design of evaluation } \\
\text { result }\end{array}$ & 5 & 5 & 4 & 5 & 19 & 95.00 \\
\hline
\end{tabular}

Referring to the conversion, and based on the data shown in Table 1 above, so trial results average of application for digital library evaluation included in the excellent category, so in general the application is ready for use and no need for improvement anymore.

The results of this study represent the answer to the obstacles found in previous studies by Divayana [31] related to limitations regarding evaluation results calculation showing the lowest value up to the highest of each evaluation component. Besides having advantages as a solution to the previous research constraints, but specifically in this study also found obstacles. The obstacles found in this study is the unavailability print out facility of the evaluation report, and backup data facility so that there is no print archive or digital archive if suddenly the application breaks.

Future works that can be done to overcome these obstacles is in the development form of evaluation application of digital library services equipped with backup data and print facility of the evaluation report.

\section{Conclusions}

The application for digital library evaluation is already good and ready to be implemented in universities. This application has been able to provide accurate calculation results using weighted product method, especially in showing the lowest value up to the highest of each evaluation component of CSE-UCLA model. Solutions that can be done to overcome obstacles in this study is to prepare the reports print facility and backup data facility.

The authors would like thanks to Director General of Higher Education on the Indonesia Republic, who provided funding in this study. The authors also would like thanks to the Rector of Universitas Pendidikan Ganesha, which provides opportunities in conducting this study and all parties who provided to support and assistance in completing this study.

\section{References}

1. D.G.H. Divayana, P.W.A. Suyasa and N. Sugihartini. Pengembangan media pembelajaran berbasis web untuk matakuliah kurikulum dan pengajaran di jurusan pendidikan teknik informatika universitas pendidikan ganesha. Jurnal Nasional Pendidikan Teknik Informatika, 5(3), 149-157 (2016)

2. D.G.H. Divayana. Evaluasi pelaksanaan blended learning di smk ti udayana menggunakan model CSE-UCLA. Jurnal Pendidikan Vokasi, 7(1), 64 77 (2017)

3. D.G.H. Divayana. Utilization of CSE-UCLA model in evaluating of digital library program based on expert system at universitas teknologi indonesia: a model for evaluating of information technologybased education services. Journal of Theoretical and Applied Information Technology, 95(15), 3585-3596 (2017)

4. D.G.H. Divayana. Evaluasi pemanfaatan e-learning menggunakan model CSE-UCLA. Cakrawala Pendidikan: Jurnal Ilmiah Pendidikan, 36(2), 280289 (2017)

5. D.G.H. Divayana. Penggunaan model CSE-UCLA dalam mengevaluasi kualitas program aplikasi sistem pakar. Seminar Nasional Teknologi Informasi \& Aplikasinya (SNATIA), 165-168 (2015)

6. D.G.H. Divayana. Evaluasi Program Penanggulangan HIV/AIDS Dengan Model CIPP Berbantuan Komputer. Konferensi Nasional Sistem \& Informatika, 442-446 (2015)

7. I.N. Suandi, I.B. Putrayasa and D.G.H. Divayana. Compiling a dictionary of loan words in balinese: the evaluation result of effectiveness testing in the field aided by mobile technology. Journal of Theoretical and Applied Information Technology, 95(14), 3186-3195 (2017)

\footnotetext{
*Corresponding author: hendra.divayana@undiksha.ac.id
} 
8. I.B.P. Arnyana, I.W. Sadia, I.K. Suma and D.G.H. Divayana. Determination of effectiveness of evaluation results on school culture and character of junior high school students using character assessment instruments with the local wisdom of bali based on mobile phone. Journal of Theoretical and Applied Information Technology, 95(20), 5348-5359 (2017)

9. I.N. Jampel, I.W. Lasmawan, I.M. Ardana, I.P.W. Ariawan, I.M. Sugiarta and D.G.H. Divayana. Evaluation of learning programs and computer certification at course institute in bali using CSEUCLA based on saw simulation model. Journal of Theoretical and Applied Information Technology, 95(24), 6934-6949 (2017)

10. D.G.H. Divayana, I.M. Ardana and I.P.W. Ariawan. Measurement of the effectiveness of a lecturer in transferring algebra knowledge through of multimedia facilities by using certainty factorformative-summative model. Journal of Theoretical and Applied Information Technology, 95(9), 1963-1973 (2017)

11. D.G.H. Divayana and D.B. Sanjaya. Mobile phonebased cipp evaluation model in evaluating the use of blended learning at school in bali. International Journal of Interactive Mobile Technologies, 11(4), 149-159 (2017)

12. D.G.H. Divayana, B.I. Sappaile, I.G.N. Pujawan, I.K. Dibia, L. Artaningsih, I.M. Sundayana and G.A.D. Sugiharni. An evaluation of instructional process of expert system course program by using mobile technology-based CSE-UCLA model. International Journal of Interactive Mobile Technologies, 11(6), 18-31 (2017)

13. D.G.H. Divayana, A.A.G. Agung, B.I. Sappaile, W. Simatupang, Y. Sastrawijaya, I.M. Sundayana and G.A.D. Sugiharni. Utilization of open source technology in determining of validity and reliability of evaluation model instruments based on ANEKA values in order to evaluate the quality of computer learning. Journal of Theoretical and Applied Information Technology, 95(20), 5517-5534 (2017)

14. D.G.H. Divayana, A.A.I.N. Marhaeni, N. Dantes, I.B.P. Arnyana and W. Rahayu. Evaluationof blended learning process of expert system course program by using a CSE-UCLA model based on mobile technology. Journal of Theoretical and Applied Information Technology, 95(13), 30753086 (2017)

15. D.G.H. Divayana, D.B. Sanjaya, A.A.I.N. Marhaeni and I.G. Sudirta. CIPP evaluation model used based on mobile phone evaluating the use of blended learning platforms at vocational schools in bali. Journal of Theoretical and Applied Information Technology, 95(9), 1983-1995 (2017)

16. D.G.H. Divayana, A. Adiarta and I.B.G.S. Abadi. Initial draft of CSE-UCLA evaluation model based on weighted product in order to optimize digital library services in computer college in bali. The Consortium of Asia-Pacific Education Universities (CAPEU) 2017, Universitas Negeri Surabaya, Surabaya, Conference Proceedings 296 (IOP
Conference Series: Materials Science and Engineering), 1-6 (2018)

17. D.G.H. Divayana, A. Adiarta and I.B.G.S. Abadi. Conceptual and physical design of evaluation program for optimizing digital library services at a computer college in bali based on CSE-UCLA model modification with weighted product. Journal of Theoretical and Applied Information Technology, 95(16), 3767-3782 (2017)

18. D.G.H. Divayana, A. Adiarta and I.B.G.S. Abadi. Development of CSE-UCLA evaluation model modified by using weighted product in order to optimize digital library services in higher education of computer in bali. Jurnal Pendidikan Vokasi, 7(3), 288-303 (2017)

19. D.G.H. Divayana, A. Adiarta and I.B.G.S. Abadi. Uji coba rancangan model CSE-UCLA yang dimodifikasi dengan metode weighted product dan validasi instrumen evaluasi layanan perpustakaan digital pada perguruan tinggi komputer di bali. Seminar Nasional Pendidikan Teknik Informatika 8, 28-34 (2017)

20. D.G.H. Divayana and G.A.D. Sugiharni. Evaluasi program sertifikasi komputer pada universitas teknologi indonesia menggunakan model CSEUCLA. Jurnal Pendidikan Indonesia, 5(2), 865872 (2016)

21. I.P.W. Ariawan, D.B. Sanjaya and D.G.H. Divayana. An Evaluation of the Implementation of Practice Teaching Program for Prospective Teachers at Ganesha University of Education Based on CIPP-Forward Chaining. International Journal of Advanced Research in Artificial Intelligence, 5(2), 1-5 (2016)

22. H.E. Wahanani, I.M. Suartana and Y.N. Hasyim. Performance evaluation of DSR with mobility models. The $3^{\text {rd }}$ Bali International Seminar on Science \& Technology (BISSTECH 2015), Bali, Indonesia, MATEC Web of Conferences 58, 03011, 1-5 (2016)

23. Y.L.Lee, K.Y. Chen, Y.W. Chen, Y.B. Chen and S.J. Liao. The design of a modified PSO guidance law using predictor and LOS rate evaluation. The International Conference on Computing and Precision Engineering (ICCPE 2015), Sun Moon Lake Teacher's Hostel, Taiwan, MATEC Web of Conferences 71, 02001, 1-3 (2016)

24. P. Xuesheng and T.Liyingi. Evaluation and study on relationship between sitting posture and work efficiency. 2017 International Conference on Electronic Information Technology and Computer Engineering (EITCE 2017), Zhuhai, China, MATEC Web of Conferences 128, 04002, 1-5 (2017)

25. Y. Li, Z. Li, B. Li and S. Hu. A Novel Reliability Evaluation Method Based on RBD and AHP for Industrial Network Systems. 2017 International Conference on Electronic Information Technology and Computer Engineering (EITCE 2017), Zhuhai, China, MATEC Web of Conferences 128, 04003, 1-6 (2017) 
26. M.A. Suhaimi, K.H. Park, S. Sharif, D.W. Kim and A.S. Mohruni. Evaluation of cutting force and surface roughness in high-speed milling of compacted graphite iron. Sriwijaya International Conference on Engineering, Science and Technology (SICEST 2016), Bangka Island, Indonesia, MATEC Web of Conferences 101, 03016, 1-7 (2017)

27. Y. Fatahillah, W. Utama, K. Suprayogi, A. Hilyah and I. Maulana. Source rock formation evaluation using TOC \& Ro log model based on well-log data procesing: study case of Ngimbang formation, North East Java basin. Sriwijaya International Conference on Engineering, Science and Technology (SICEST 2016), Bangka Island, Indonesia, MATEC Web of Conferences 101, 04016, 1-6 (2017)

28. J.T. Burhani, F.Zukhruf and R.B. Frazila. Port performance evaluation tool based on microsimulation model. Sriwijaya International Conference on Engineering, Science and Technology (SICEST 2016), Bangka Island, Indonesia, MATEC Web of Conferences 101, 05011, 1-5 (2017)

29. S. Calmanoa, D. Hesse, F. Hoppe and P. Groche. Evaluation of control strategies in forming processes. $4^{\text {th }}$ International Conference on New Forming Technology (ICNFT 2015), Glasgow, UK, MATEC Web of Conferences 21, 04002, 1-7 (2015)

30. J. Xu, G. Xing, D.Shan, B. Guo, and T.G. Langdon. An evaluation of formability using micro-embossing on an ultrafine-grained magnesium AZ31 alloy processed by high-pressure torsion. $4^{\text {th }}$ International Conference on New Forming Technology (ICNFT 2015), Glasgow, UK, MATEC Web of Conferences 21, 09005, 1-7 (2015)

31. D.G.H. Divayana. Evaluasi Program Perpustakaan Digital Berbasis Sistem Pakar Pada Universitas Teknologi Indonesia. Jakarta: Program Pascasarjana Universitas Negeri Jakarta, 2016

32. W.R. Borg and M.D. Gall. Educational Research: An Introduction, Fifth Edition. New York: Longman, 2008

33. D.G.H. Divayana. 2014. Development of duck diseases expert system with applying alliance method at bali provincial livestock office. International Journal of Advanced Computer Science and Applications, 5(8), 48-54 (2014)

34. A. Ahmadi and D.T. Wiyanti. Implementasi weighted product (wp) dalam penentuan penerima bantuan langsung masyarakat pnpm mandiri perdesaan. Proceedings Seminar Nasional Aplikasi Teknologi Informasi (SNATI), 19-22 (2014)

35. I.M. Ardana, I.P.W. Ariawan and D.G.H. Divayana. Development of Decision Support System to Selection of the Blended Learning Platforms for Mathematics and ICT Learning at SMK TI Udayana. International Journal of Advanced Research in Artificial Intelligence, 5(12), 15-18 (2016)
36. M. Subana and Sudrajat. Dasar-Dasar Penelitian Ilmiah. Bandung: CV. Pustaka Pelajar, 2001 